\title{
Sĕrat Dahor Palak, Sastra Islam Abad XVII
}

\section{Fajar Wijanarko}

Tepas Tandha Yekti, Kraton Yogyakarta

\begin{abstract}
Islam and the dimensions of public believe in Java have their own way to sneak around and survive. Both have an equal position till the society find the now concept, which is Islam Jawa. It is a belief that accommodates between Islam and the traditional beliefs system. The fact of them is also happening on writing era of a manuscript. The last, Syncretism and Sufism are became commonplace in the understanding and development of Islamic literature, which one is Serat Dahor Palak (SDP). The truth of syncretism would be wrote based on philology approach and method of library research. Inside include of local wisdom from the manuscript which talks about the prophet is way in Hinduism era.
\end{abstract}

\begin{abstract}
Abstrak
Islam dan dimensi kepercayaan masyarakat Jawa memiliki cara masing-masing untuk menyelinap sekaligus bertahan. Keduanya mempunyai kondisi yang sama kuat sehingga lahirlah konsep Islam-Jawa sebagai sistem kepercayaan yang mengakomodasi pengaruh Islam terhadap sistem kepercayaan masyarakat Jawa. Kenyataan serupa turut terjadi pada penulisan karya Sastra Islam. Pada akhirnya, sinkretisme dan tasawuf menjadi media yang menjembatani perkembangan sastra Islam, salah satunya pada Sĕrat Dahor Palak (SDP). Bentuk sinkretisme tersebut selanjutnya akan diungkapkan melalui pendekatan filologi dan metode studi kepustakaan. Termasuk pula kazanah cerita para nabi dan kehidupan umat di zaman para nabi pun akan turut diungkapkan sebagai wujud dari kekayaan Sastra Islam di era sistem kepercayaan masyarakat pada masa penyalinan teks.
\end{abstract}

Keywords: Syncretism, Islam Java, Sufism, Text SDP

DOI: 10.22515/shahih.v2i1.680 


\section{Pendahuluan}

Anĕmbah sira mring pangeranipun/ kang akarya bumi langit/ miwah sira lawan ingsun/ kang akarya pati urip/ nebuta kalimah roro// As hadu alla ila haillallahu/ lan as hadu anna malih/ wanuh kang nabi yullahu/ iku ugĕring ngaurip/

Menyembahlah engkau pada Pangerannya (yaitu) yang mencipta bumi dan langit, dan juga engkau dan aku, yang menjadikan hidup dan mati. Ucaplah dua kalimat itu, As hadu alla ila haillallahu, dan lagi as hadu anna nabi yullahu. Demikian pedoman dalam hidup.

(Dahor Palak, Megatruh 5-6)

Pada kenyataannya Animisme, Dinamisme, Hindu, dan Buddha telah ada sebelum era Majapahit. Sebuah paradigma yang mengakar kemudian menjadi identitas yang diperkuat dengan produk budayanya. Salah satunya tahun Saka menjadi pola pembabagan produk Hindu sebagai parameter dari penanda kebangkitan tradisi tulis (Simuh, 1984, p. 1). Bermedia simbol, peradaban pada periode tahun Saka ini dibicarakan melalui kronogram sejarah, hingga dominasi Islam di awal abad pertengahan masuk melalui celah-celah sastra pesisiran (De Graaf, 1989, p. 3). Poerbatjaraka ${ }^{1}$ (1952) menyebutkan bahwa pesisiran sebagai jalur strategis masuknya cerita Islam dari tanah Persi. Perjalanan Sastra Islam kemudian banyak disadur dalam bahasa Melayu, diadopsi dan disesuaikan dengan ekologi Jawa sebagai kitab-kitab (Simuh, 1984, pp. 8-9). Peradaban inilah yang selanjutnya menjadi cikal-bakal Islam Jawa. Kondisi saat warisan pemahaman, tradisi, dan keteraturan yang telah digumuli sejak masa leluhur melahirkan jarak antara leluhur dan keyakinan yang seolah-olah menjadi perpaduan dari tradisi Jawa dan unsur-unsur Islam. Greertz (1960) menguatkan pendapat dengan menggolongkan Islam Jawa ke dalam 3 unsur, abangan, santri, dan priyayi, termasuk pula tradisi susastranya (Kuntowijoyo, 1984, p. 1).

Kalangan istana sebagai representasi priyayi menjadi benteng-benteng tebal yang memberi jarak antara masyarakat abangan dan golongan santri. Tidak ada kontrol yang jelas antara ketiga penggolongan tersebut. Sampai sejarah Surakarta mencatat semenjak 1744 pertumbuhan sastra Islam-Jawa berada di puncaknya. (Drewes, 1974, p. 199) ${ }^{2}$ menyebutkan bahwa periode ini berlangsung selama 125 tahun (antara 1757-1873) yang ditandai dengan wafatnya pujangga terakhir R. Ng. Ranggawarsita, atau bahkan sampai tahun 1881 dengan mangkatnya Mangkunegara IV. Peristiwa tersebut bukan tanpa alasan sebab semenjak kolonialis Belanda masuk ke jantung-jantung keraton dan memecahnya menjadi 3 kerajaan, Surakarta, Yogyakarta, dan Mangkunegaran, perhatian dan kegiatan istana diarahkan bagi 
perkembangan kebudayaan rohani (Simuh, 1984, p. 10) Kondisi di luar tembok keraton dihadirkan pada kenyataan bahwa pondok dan pesantren tumbuh subur sebagai tempat belajar ilmu agama sekaligus tempat tumbuhnya kesusastraan Islam. Motif-motif syariat sebagai induk bagi pembelajaran agama menjadi motif utama yang kerap ditulis. Sedangkan pada konteks istana sebagai pemangku Islam-Jawa, motif yang sering muncul adalah tasawuf (mistik Islam). Produk pustakanya lazim dikenal dengan sebutan primbon, wirid, dan suluk $^{3}$ (Pujiastuti, n.d., 2006, pp. 3-4). Motif tasawuf yang dituliskan dalam bentuk wirid (prosa) dan suluk (puisi) menjadi media dalam membingkai ajaran budi luhur.Varian lain adalah primbon yang nampaknya lebih menarik dengan ajaran-ajaran yang disusun tanpa struktur, seperti ngelmu petung, ramalan, guna-guna, pelajaran ibadah, akidah, hingga yang diwujudkan dalam bentuk cerita (baik prosa atau puisi), seperti Sĕrat Kandha, Paramayoga, Sěrat Ambya, Sĕrat Menak (Simuh, 1984, p. 1). Lebih menariknya dari teks tersebut muncul tĕdhakan (tradisi penyalinan ulang) yang bersumber dari teks induk (babon) sebagai upaya melestarikan kandungan isi maupun sebagai sarana legitimasi penguasa. Salah satu jenis primbon Islam Kejawen yang ditulis dalam bentuk puisi adalah teks Dahor Palak yang merupakan tĕdhakan dari Sĕrat Ambya ${ }^{4}$, baik penyalinan versi pesantren maupun versi kerajaan (Behrend, 1990, pp. 3-4; 207-8).

Persoalannya adalah salinan dari teks Ambya koleksi museum negeri Sonobudoyo berjumlah 30 naskah dan tidak hanya di tulis menggunakan aksara Jawa, tetapi juga dengan aksara Pegon. Oleh karenanya, perlu diperkirakan teks induk terdekat yang menjadi acuan dari penyalinan. Melalui pendekatan filologi dengan metode studi kepustakaan kandungan teks dari SDP juga akan turut diungkapkan termasuk berbagai kemungkinan terkait perkembangan Sastra Islam di istana.

\section{Sĕrat Dahor Palak:Tinjauan Awal}

Di dalam katalog (Behrend, 1990), terdapat 2 naskah Sĕrat Dahor Palak (SDP) dengan kode S1 (SK 100) berjudul Sĕrat Dahor Palak ${ }^{5}$ dan kode S3 (PBE 100) berjudul Sĕrat Jatipusaka (Dahor Palak) saha Sĕrat Momana ${ }^{6}$. Akan tetapi, tulisan ini dibatasi pada ulasan teks SDP kode S1 (SK 100) (h.1-24) berdasarkan cara kerja kolaboratif antara filologi sebagai kajian tentang kandungan naskah, paleografi sebagai kajian tentang perkembangan aksara atau corak tulisan dan kodikologi sebagai kajian tentang fisik naskah. Kerja kolaboratif ini dimaksudkan agar memperoleh informasi sejelas-jelasnya mengenai teks.

Kajian teks dengan arti gelap pernah diutarakan oleh (Molen, 2011, pp. 94-95) dalam penelitiannya terhadap teks Kunjarakarna. Menurutnya, membedah teks tidak dapat dilakukan berdasarkan sumber mandiri sehingga informasi eksternal diperlukan dalam mengungkap teks secara komprehensif. Pada kasus Teks SDP sebagai salinan dari Ambya 
masih belum jelas teks induknya. Keterangan (Behrend, 1990) hanya menyebutkan bahwa SDP sebagai turunan dari teks pesantren yang populer di Jawa, dan dimungkinkan seperti halnya kesenian, teks ini diboyong oleh carik-carik istana untuk ditulis versi keraton (Behrend, 1990, p. 1). Identitasnya sebagai salinan teks dibubuhkan oleh penyalinnya sebagai tarikh di akhir halaman:

"Ingkang kapĕthik ing cariyos nukil saking kitab Ngumdatul Ansab, lan saking tapsir Suleman Jamal, tuwin sangking pĕthikan srat Babad ing Matawis..." (SDP, 59).

Ditulis dari petikan ringkasan cerita kitab Umdatu'l-Ansab, serta dari tafsir Sulaiman Jamal dan juga dari petikan serat Babad Mataram

Pada keterangan yang disebutkan oleh carik nampak jelas bahwa sastra istana turut memberi pengaruh pada tradisi penyalinan teks SDP. Melalui keterangan tersebut, maka metode perbandingan aksara sangat wajar digunakan dalam penentuan paleografis tulisan. Berdasarkan olah data inventarisasi paleografi dari ke-30 teks, corak penulisan yang hampir serupa adalah naskah Tajusalatin ${ }^{7}$ yang terdiri dari 3 teks, Tajusalatin, Sĕrat Wulang Pinalupi, dan Sĕrat Ambya. Corak penulisan ngĕtumbar (menyerupai buah ketumbar), penomoran halaman, dan sistem penanggalannya menjadi tanda terang bahwa penyalinan teks berada di kompleks istana, atau setidaknya unsur paleografi istana mendominasi penulisan teks. Corak istana jauh lebih ditunjukkan oleh teks SDP dengan adanya bubuhan wĕdana ${ }^{8}$ rĕnggan dan rĕrĕnggan pada setiap pergantian pupuh ${ }^{9}$ yang bercerita episode para nabi. Bubuhan aksara Arab pun menjadi bagian dari hiasan pada lembar-lembar naskah, khususnya di awal pergantian cerita. Hal tersebut secara eksplisit dapat diuraikan pada tabel berikut:

\begin{tabular}{|c|c|c|c|l|}
\hline No & Pupuh & Pola Wĕdana & Halaman & \multicolumn{1}{|c|}{ Keterangan } \\
\hline 1 & Dhandhanggula & Wĕdana Rĕnggan & (h.1-2) & $\begin{array}{l}\text { Lafal arab membingkai: } \\
\text { Al hamdu lillahi rabbil alamin/ Ar } \\
\text { Rahman. }\end{array}$ \\
\hline 2 & Asmaradana & Wĕdana Rĕnggan & (h.5-6) & $\begin{array}{l}\text { Ilustrasi burung, naga, tombak. Lafal } \\
\text { arab berada di bagian mahkota: } \\
\text { La ilaha illallah/ Muhammadur } \\
\text { Rasulullah. }\end{array}$ \\
\hline 4 & Megatruh & Rĕrĕnggan & (h.9) & $\begin{array}{l}\text { Ilustrasi naga, yang ditarik ekornya } \\
\text { oleh tikus dan setan, berada di bawah } \\
\text { lingkaran dikelilingi api dengan } \\
\text { mahkota bunga. }\end{array}$ \\
\hline 5 & Pangkur & Rĕrĕnggan & (h.13) & $\begin{array}{l}\text { Ilustrasi masjid dengan sepasang } \\
\text { menara di kanan dan kiri. } \\
\text { arsitek pintu masjid. }\end{array}$ \\
\hline 6 & Kinanthi & Rĕrĕnggan & (h.15) & $\begin{array}{l}\text { Tampak sulur dengan sepasang } \\
\text { burung di kanan dan kiri seperti } \\
\text { gambaran dari bangunan taman di } \\
\text { istana. }\end{array}$ \\
\hline
\end{tabular}




\begin{tabular}{|c|l|l|l|l|}
\hline 7 & Dhandhanggula & Wĕdana Rĕnggan & (h.19-20) & $\begin{array}{l}\text { Ilustrasi sayap, kuncup teratai, dan } \\
\text { sulur-sulur. Lafal Arab berada di } \\
\text { bagian mahkota: La Ilaha Illallah, } \\
\text { dan di bagian bawah bertuliskan } \\
\text { Muhammadur Rasulullah. }\end{array}$ \\
\hline
\end{tabular}

Jika dibandingkan dengan Sĕrat Jatipusaka (Dahor Palak) saha Sĕrat Momana, umur teks SDP jauh lebih tua. Terdapat rentang jarak 67 tahun antara waktu penulisan pada 1845 dengan waktu penyalinan pada 1912. Namun, penyalinan tetap patuh untuk menyebutkan tarikh pada teks yang baru sesuai dengan teks induk terlebih, dalam satu naskah Sĕrat Jatipusaka (Dahor Palak) terdapat dua teks, yaitu Dahor Palak sebagai teks 1 dan Sërat Momana sebagai teks 2 yang menceritakan sejarah tanah Jawa sejak Abuyaksa hingga pernikahan HB V dengan G.K.R. Kencana tahun 1833-1834.

Catatan terpenting bagi peneliti naskah selanjutnya adalah kandungan teks SDP dengan turunannya tidaklah berubah. Konsistensi penyalinan menyesuaikan dengan teks induk termasuk pada setiap perubahan episode cerita. Pada episode di awal teks berisi kronogram nabi, keluarga, dan para sahabat yang dibagi menjadi 9 pupuh. Uraian tersebut dapat dilihat pada tabel berikut:

\begin{tabular}{|c|l|c|l|}
\hline No & \multicolumn{1}{|c|}{ Pupuh } & $\begin{array}{c}\text { Jumlah } \\
\text { Pada }\end{array}$ & \multicolumn{1}{|c|}{ Kronogram Nabi } \\
\hline 1 & Dhandhanggula & 14 & Tarikh penyalinan teks, kronogram Nabi Adam. \\
\hline 2 & Asmaradana & 16 & $\begin{array}{l}\text { Diawali kronogram Nabi Adam, berputra Nabi Sis yang } \\
\text { digadang sebagai penggantinya. }\end{array}$ \\
\hline 3 & Megatruh & 14 & Kronogram Nabi Nuh, sahadat Islam. \\
\hline 4 & Mijil & 13 & $\begin{array}{l}\text { Diawali kisah Nabi Ibrahim, dilanjutkan dengan kisah umatnya } \\
\text { yang kafir dan kelahiran nabi selanjutnya, Ismail dan Ishake. }\end{array}$ \\
\hline 5 & Pangkur & 11 & Kronogram Nabi Musa dan kaum Bani Israil di Mesir. \\
\hline 6 & Kinanthi & 15 & $\begin{array}{l}\text { Diawali kisah Nabi Isa, diberikannya kitab Taurat dan cerita } \\
\text { Dewi Maryam sang ibu. }\end{array}$ \\
\hline 7 & Sinom & 11 & $\begin{array}{l}\text { Diawali kronogram Nabi Ayub dan Sultan Sulaiman, } \\
\text { dilanjutkan dengan gambaran azab kaum Nabi Nuh, Nabi } \\
\text { Shaleh, Nabi Hud, Nabi Ibrahim, dan Nabi Lut. Pupuh diakhiri } \\
\text { dengan menjelaskan tugas malaikat Jibril, Isrofil, dan Izroil. }\end{array}$ \\
\hline 8 & Dhandhanggula & 12 & $\begin{array}{l}\text { Kronogram Nabi Muhammad hingga berganti pada kisah } \\
\text { empat Sahabat Nabi, Khalifah. }\end{array}$ \\
\hline 9 & Asmaradana & 15 & $\begin{array}{l}\text { Kronogram Abu Bakar, Umar, Sultan Sayidin Usman, dan } \\
\text { Sultan Sayidin Ali. }\end{array}$ \\
\hline
\end{tabular}

\section{Dialog Islam Pada Kronogram SDP}

Masyarakat Jawa di awal telah disebutkan sebagai pewaris dari kepercayaan religi animisme-dinamisme dan Hindu yang berdampingan dengan Islam. Bahkan, masuknya Islam tidak mematikannya, melainkan menyuburkannya(Simuh, 1998, p. 122). Peristiwa ini 
terjadi pula pada sastra-pesantren yang diproduksi di kalangan istana, seperti halnya SDP. Islam seolah bermimikri menyesuaikan konteks sosial-budaya masa penulisannya. Termasuk lingkungan aristokrat yang memberi warna corak aksara sebagai aturan baku pada sastrasastra produksi keraton.

Perihal sederhana yang ditemukan dalam teks SDP adalah istilah Allah yang lazim digunakan oleh masyarakat santri untuk mengistilahkan sang Pencipta. Periode penulisan dan penyalinan teks pada abad XVII masih berada pada nuansa pra-Islam termasuk nuansa Hindu dengan menempatkan penyebutan Dewa dan Tuhan pada fase tertinggi dalam lingkaran penciptaan makhluk, seperti Ywang, Ywang Agung, Ywang Manon, Ywang Widi, Ywang Suksma, Widi, dan sekadar Manon. Semuanya merujuk pada tujuan pemahaman yang sama, yaitu Tuhan sebagai penguasa alam raya. Dapat dikatakan, bagian ini adalah episode dari sinkretisme pada teks-teks Islam saduran kerajaan (Samidi, 2016, p. 16).

Di dalam sejarahnya, Islam sinkretis telah dikenalkan oleh Sultan Agung yang berhasil menyinkretiskan ajaran dan pemahaman Islam dengan budaya Jawa melalui sastra. Tidak hanya di kalangan bangsawan keraton, masyarakat pedesaan turut mengambil peran dari pemahaman baru tanpa menggeser warisan nenek moyang. Suluk, wirid, dan primbon adalah jenis-jenis karya sastra pasca-Islam yang mengambil andil dalam perkembangan sastra Jawa sinkretis dan menempatkannya sebagai dokumen tulis dari perkembangan keyakinan baru ini ${ }^{10}$ (Prabowo dkk, 2003, p. 22). Pandangan (Wirjosaputro, 1964, p. 6) eolah mendukung bahwa tasawuf apalagi primbon menjadi media awal pendekatan Islam pada sistem kepercayaan yang sudah mengakar ratusan tahun silam.

However, one thing certain: the Indonesia knew a certain type of rites, showing the adventures of their ancestors. These religious rites were considered a means of maintaining contact between them and their ancestors. By performing these rites the prosperity of their community could be maintained. As the souls of the acesters were supposed to have the shape of shadow (Wirjosaputro, 1964, p. 6).

Bagaimanapun suatu hal yang pasti bahwa Indonesia telah mengenal satu bentuk tertentu dari upacara religi, kaitannya dengan kehidupan roh nenek moyang.Sistem kepercayaan ini dipandang sebagai upaya melestarikan hubungan mereka dengan leluhur. Dengan melaksanakan upacara seperti yang dipercaya, maka kesejahteraan hidup mereka akan terpelihara, karena roh nenek moyang mengambil bentuk seperti bayang-bayang.

Pada tradisi penulisan dan penyalinan teks, pujangga yang kerap tidak menyebutkan identitasnya bukan berarti karena tidak mengenal Islam dengan baik. Sebab, faktanya pada teks $S D P$ sebagai produk tradisi tulis istana melegalkan paham Islam di kalangan pujangga yang telah mengenal cerita nabi-nabi di awal abad XVII dan dimungkinkan sudah dikenal jauh sebelum Islam-Jawa mulai ditulis. Dimulai dengan kronogram nabi Adam yang diturunkan di bumi, 
Ngisikhi kayating nabi/ Adam phitatullaha/ mongka kalipahing Manon/ murwani sagung manungsa/ tuku abu basara ${ }^{11} /$ nging babuning roh jëng rasul/ Mukhamadinil Mustapha//Jěng nabi Adam kawarani/ tumurunakĕn nung dunya (h.6)/ nuju mukharam sasine/ marengi tanggal ping tiga/ tumamongsa lan arga/ ing wit amanggih sesiku/ rahine wus pĕsthining// (SDP, Asmaradana 1-2).

Dikisahkan perjalanan nabi Adam, sebagai 'phitatullaha' yang dianggap sebagai utusan Tuhan (sekaligus) mengawali lahirnya manusia (yang) dibuat dari tanah bersinar, berasal dari roh ibu Kanjeng Rasul Mukhamadinil Mustapha. Dikisahkan kanjeng nabi Adam, (saat) diturunkan ke bumi, pada bulan Muharram, tepat di tanggal ke-3, waktu tuma dan arga (gunung), ditemukan diantara jurang gunung, (sebab) lahirnya sudah menjadi takdirnya.

Diceritakan nabi Adam sebagai utusan Allah, berperan khalifatullah 'phitatullah' di dunia yang mengawali penciptaan manusia dari tanah (yang bersinar), benih yang baik. Hingga kronogram diturunkannya ke muka bumi. Dituliskan pada teks tersebut bahwa turunnya nabi Adam pada 3 Muharram, waktu tuma. Demikianlah takdir yang harus diperolehnya akibat tergoda olah bujukan nafsu. Di pada selanjutnya (Asmaradana 8-9) bahwa nabi Adam berputra nabi Sis dari dewi Kawa (Hawa).

Lĕstari kang palakrami/ malih jĕng nabi pĕputra/ tan sarta lawan garwane/ dadi sing pamuja montra/ wis sĕlaya lan garwa/ kakung warnanira bagus/ antuk nugrahaning Suksma//Sinungan nama nabi Sis/ langkung sih ira kang rama/ ginadhang kaluhurane/ miwah sang dyah dewi Kawa/ kalintang trĕsnanira/ lir denya yĕyoga tuhu/ ketang sih ira Ywang Suksma// (SDP, Asmaradana 8-9).

Langgeng pernikahannya maka teruslah nabi berputra dari istrinya, jadilah yang keduanya sang pendoa, (yang) sudah sependapat dengan sang istri, berputra yang berwajah rupawan karena mendapat anugerah dari Tuhan. Diberilah nama Nabi Sis, jauh lebih mengasihi (dari) ayahnya, digadang keluhurannya. Maka, sang Dewi Kawa berlebih rasa kasihnya kepada sang putra dengan sungguh-sungguh, (maka) ingatlah kasihnya sang Pencipta.

Di akhir hayatnya, nabi Adam memiliki banyak putra yang telah tercerai-berai keberadaannya. Hanya tinggal nabi Sis (dari Dewi Kawa) yang senantiasa mendampingi. Melalui nabi Sis, gelar kenabiannya diturunkan ${ }^{12}$ hingga diusia 960 tahun, Nabi Adam wafat ${ }^{13}$. Pada pupuh selanjutnya (Megatruh), diceritakan umat pada masa Nabi Nuh yang memperoleh gelar kenabian dari Ywang Manon diusia 60 tahun setelah Nabi Adam. Diceritakan pula umat Nabi Nuh gemar menyembah berhala.

Mĕgat gita kontap ruwiyeng nabi Nuh/ tuhu kĕkasihing Widi/ kamatyan ingkang jëjuluk/ Nuh kang nabiyulahi/ pinardika ing Ywang Manon//Amangsuli kandhanira kang karuhun/ jĕng nabi Nuh duk angsal/ tĕtĕp nabi warusulu/ yuswa sawidak warsi/ lan nabi Adam sang kaot//(SDP, Megatruh 1-2). 
Anĕmbah sira mring pangeranipun/ kang akarya bumi langit/ miwah sira lawan ingsun/ kang akarya pati urip/ nebuta kalimah roro//As hadu alla ila haillallahu/lan as hadu anna malih/ wanuh kang nabi yullahu/ iku (h.10) ugĕring ngaurip/ ywa nĕmbah rĕca gung ing wong//Ing sayĕkti panggaweing setan ngridhu/ yata sakathahing kapir/ tita tan ana mituhu/ malah juwiyah mring nabi/ weneh mrih bilahi kang wong//(SDP, Megatruh 5-7).

Megat(truh) tembangnya, yang terkenal cerita Nabi Nuh, nyata kekasih sang Pencipta, berlebih panggilannya sang (nabi) Nuh nabiyulahi, (yang) berarti utusan Tuhan. Menjawab ujarnya dahulu, saat jeng Nabi Nuh diperolehkan menjadi nabi Warusulu, diusia 60 tahun oleh nabi Adam yang termasyhur.

Menyembahlah engkau kepada sang Pangeran, yang mencipta bumi dan langit, (menciptakan pula) engkau dan aku, yang menjadikan hidup dan mati, (maka) ucaplah dua kalimat itu, As hadu alla ila haillallahu, dan lagi as hadu anna nabi yullahu. Demikian pedoman dalam hidup, bukan (justru) menyembah berhala yang diagungkan oleh orang. Itukah sungguh perbuatan setan menggoda, lantas banyak yang kafir. Sudah terlewat dan tak ada yang percaya, malah juwiyah (menghina?) nabi, dan lagi membuat orang celaka.

Meskipun Nuh telah menjadi nabi Warusulu masih mendapat keraguan atas umatnya. Bahkan telah diutarakan untuk berpedoman pada 2 kalimat sahadat (Anna nabi yullahu, sebagai penyebutan sahadat sebelum masa Rasulullah Muhammad), tetapi diabaikannya. Umatnya banyak yang kafir akibat godaan setan. Demikian itulah, orang yang akan celaka. Sejenak berhenti pada episode kafir yang tidak mengakui 2 kalimat sahadat. Pada kalimat tersebut terlihat perjalanan asimilasi Islam dengan ekologi Jawa. Meskipun dirasa tidak mendapat hasil signifikan dari segi pemeluknya, tetapi dalam dunia sastra abad XVII, Islam telah fasih dibicarakan. Tarikh-tarikh sejarah Islam di masa lampu dituliskan sebagai upaya pendidikan pembaca teks di era selanjutnya.

Berikutnya pada pupuh Mijil, diceritakan kronogram nabi Ibrahim yang berada di kalangan umat kafir. Ia adalah nabi terpilih di antara orang-orang unggulan yang berada di sekelilingnya. Dengan penuh keyakinan kepada sang Pencipta tanpa perantara, Ibrahim menegakkan jalan agama Ywang Manon, hingga dilanjutkan oleh kedua anaknya, Nabi Ismail dan Ishake yang dinasihati oleh Nabi Ibrahim agar senantiasa menjalankan perintah dari sang Pencipta.

Wijilireng nugraning nabi/ Ibrohim sang kaot/ kasihing Ywang pinjulinging akeh/ tuhu manik musthikaning bumi/akathah pranabi/ ing mangsa puniku//Datan kadya jĕng nabi Ibrahim/ sih ireng Ywang Manon/ sinung srengat murweng raharjane/ sinung jejuluk Khalillalahi/ pinarcayeng Widi/ monah satru kupur// (SDP, Mijil 1-2).

Mila nabi sru mĕrdi mring siwi/ kang atmaja (h.12) roro/ Jĕng Ismangil lan nabi Iskhake/ sěbdeng rama heh nak ingsun kalih/ den padha nĕstiti/ mring pakon Ywang Agung// (SDP, Mijil 6) 
Lahirlah anugerah kenabiannya, Ibrahim yang termasyhur. Dicintai oleh Tuhan dengan melimpah, (dijadikan) sungguh sebagai mustika di bumi, meski banyak para nabi di saat itu. Tidak seperti (selain) Nabi Ibrahim, kasihnya kepada sang Tuhan, dikarenakan syariat untuk mendapat keselamatan. Itulah yang disebut Khalillahi, percaya kepada Tuhan, demikian musuhnya (orang) kafir.

Maka nabi menyeru kepada anaknya, kedua anak (bernama) Jeng Ismail dan Nabi Ishake. Ujar sang rama kepada keduanya, "Haruslah kalian něstiti(tekun), pada perintah dari sang Pencipta"

Konsep sang Pencipta (Tuhan) pada episode ini tampaknya telah serupa dengan benak masyarakat Islam, yang menempatkannya pada tataran tertinggi tanpa perantara. Kondisi sastra demikian tidak terlepas dari pujangga yang dimungkinkan telah memeluk Islam pula sebagai sistem kepercayaannya. Sebab akan menjadi gamang ketika pujangga mengalami kekeliruan dalam menulis sebuah legitimasi raja.

Perjalanan sastra Islam serupa dengan jejak para nabi yang bermuara pada Muhammad. Tidak bertindak secara serta merta hadir tanpa proses, melainkan silih berganti pada sistem pemerintahan umatnya. Seperti halnya Musa yang dianugerahi Kitab Taurat sebagai pedoman hidup. Ajaran agama suci (tauhid) yang secara implisit singkat ditulis, dimaksudkan untuk diteladani oleh pengikutnya.

Ing Ywang kĕng zallawangalza/ pan akathah mangsa iku pra nabi/ tan kadi Musa nabiyu/ sinung pěngwasa mring Ywang/ murweng srengat pinaring Kitab Toret/ marentah ing jagat raya/ amĕrdi agama suci// (SDP, Pangkur 2)

(Menyembahlah) pada Tuhan Zallawangalza saja, meski banyak saat itu para pemimpin (nabi), (namun) tidak seperti Nabi Musa, yang memperoleh anugerah dari Tuhan, dimulai dengan diberikan kitab Taurat (untuk) memerintah di dunia, mengajarkan agama suci.

Cerita teks SDP dilanjutkan pada kisah nabi Isa (putra Dewi Maryam). Memperoleh gelar kenabian adalah kodrat, semua perjalanan tanggung jawab yang harus dipikul oleh Nabi Isa ${ }^{14}$. Pada cerita ini tidak diuraikan dengan panjang kenabiannya, hanya awal pupuh yang menyebutkan bahwa Isa adalah nabi kekasih sang Pencipta '... Ima anbiya rasulli, jĕng nabi Ngisa roh khollah, tuhu kĕkasihing Widi. Berbeda pada cerita nabi-nabi sebelumnya, pada cerita Nabi Sulaiman, diilustrasikan pula kisah umat nabi yang durhaka. Cerita dimulai dengan kronogram Sulaiman ketika memuliakan Nabi Yusuf:

Tan supe ngibadahira/ ana critaning kadis/ muktining wong ahli swarga/ sor kratoning Slaman nabi/ kang wong tinitah sigit/ engeta bagendha Yusup/ tan ngetang warna pelag/ mung Allah ingkang kaesthi/ aja kaya wong merdud nĕrak duraka/l

Tidaklah lupa ibadahnya, ada lagi cerita nabi sebagai seorang yang ahli surga. Di bawah perintah dari Nabi Sulaiman, seseorang yang ditakdirkan baik (budi), ingatlah (ia) Baginda Yusuf, tak terhitung kebaikannya. Semoga Allah senantiasa memasyhurkannya, tidak seperti orang yang membangkang (imbalannya) neraka. 
Sulaiman dalam kisahnya bersama Ratu Bilqis, adalah seorang nabi sekaligus raja yang kaya raya. Pengetahuan 'kisah' ini seolah-olah telah dicerna begitu baik oleh penulis, sebab penyebutan Kratoning Slaman nabi sangat jelas merujuk pada hierarki penguasa pada era abad ke-18 (atau lebih tua) yang merujuk pada istana. Pada pupuh ini pula kronogram peristiwa dari nabi-nabi terdahulu diungkapkan. Sangat dimungkinkan sebagai upaya pembelajaran bagi generasi pembaca teks selanjutnya.

Yen ngilo bagus kang warna/ lali mring Ywang Maha Suci/ těkabur bagusing warna/ gunaning nglenceri estri/ kang sring mutung mring Widi/ eling bagendha Yunus/ tëmah den untal minal kathah yen rinenggeng kawi/ lĕlakone pra nabi kang mursalina// Jamaning para Anbiya/ umat yen balileng nabi/ sak kal kukuming Ywang Suksma/ sarta panuwuning nabi/ kaya kĕlěming bumi/ duk alame bandha Nuh/ Nabi Saleh kang utama (h.18), K.18 sirna kabuncang ing angin/ duk nabi Hud umate sinambĕr glap//...

Dene wĕktuning Anbiya/ kang gĕlar srengating bumi/ antarane lan ing wuntat/ jaman pitrah den arani/ kang tĕtĕp dadi kapir/ maido srengating pungkur/ luwih kang nĕmba rěco/ iku kang aslining kapir/ de kang durung kambah prentah srengat anyar//(SDP, Sinom, 5-6; 8).

Jika bagus rupawan saat bercermin, lupalah kepada sang Maha Suci, takaburlah pemilik wajah rupawan itu, (malah) digunakan untuk menduakan istri, yang kerap kecewa dengan sang Pencipta, (maka) ingatlah Baginda Yunus, yang ditelan oleh ikan. Masih banyak lagi yang diilustrasikan dengan kawi, perjalanan hidup para nabi sebagai utusan. Di zamannya para nabi, umat yang tidak patuh padanya, seketika dihukum oleh Tuhan, serta permohonan nabi, seperti ditenggelamkannya ke dalam bumi, pada masa umatnya Nabi Nuh. Keutamaan Nabi Saleh, (umatnya) sirna diterpa angin. Pada masa Nabi Hud, umatnya disambar petir besar.

Tibalah waktunya para nabi, yang bergelar syariat di bumi, diantara (para nabi) yang menjadi penutup. Di zaman yang suci sebutnya, yang tetap menjadi kafir dan menolak syariat (nabi) terakhir, lebih menyembah berhala, itulah yang sesungguhnya kafir, sebab belum tersentuh perintah dari syariat yang baru.

Pada kutipan di atas, cerita dimulai dari nabi Yunus yang ditelan oleh ikan dan peringatan Allah kepada umat para nabi. Jika tidak taat pada perintah Tuhan) ketika akan mendapat hukuman. Kausalitas dalam Islam diutarakan dengan gambaran umat Nabi Nuh yang ditenggelamkan ke dalam umi, atau umat Nabi Saleh yang diterpa angin, serta umat Nabi Hud yang disambar petir besar. Hingga di akhir erita dituliskan oleh pujangga tentang nabi penutup dan umat yang masih tetap kafir, sebab belum tersentuh oleh syariat ${ }^{15}$. Nabi yang dikenal dengan gelar Rasullah, kabibollah umiyil nabi (Rasul Allah, nabi yang cerdas kekasih Allah) diuraikan pada pupuh Dhandhanggula:

Manis kongas wĕkasaning nabi/ jĕng Mukhamad tuhu rasullulah/ tĕtunggiling jagat kabeh/ kathah ingkang jëjuluk kabibollah umiyil nabi/ mustapha niyakengrat/ sapingul umatu/ assayidina ambiya warusulla/ lan kathah asmaning nabi/ nanging tan cinarita//Artenira kang 
rasullahi/ pan utusaning Allah tangala/ beda lan pra nabi akeh/ kabiballah satuhu...(SDP, Dhandhanggula 1-2).

Harum semerbak diawal (cerita) nabi/ jeng Mukhamad nyata (sebagai) rasulullah. Seluruh alam raya semua, banyak yang menyebutnya nabi yang Kabibollah Umiyil ${ }^{16}$, yang terpilih sebagai raja di bumi, Sapingul umatu assayidina ambiya warusulla, dan banyak lagi nama-nama nabi, namun tidak diceritakan.Rasullahi berarti utusan dari Allah Tangala, berbeda dengan para nabi semua, (mereka) sebenarnya hanya Kabiballah (kekasih Allah)...

Sepeninggalan sang Baginda Rasul, kepemimpinan Islam dilanjutkan oleh para Sahabat ${ }^{17}$. Teks ditulis pada pupuh akhir Asmaradana sebelum berpindah pada cerita Rajaraja Mataram hingga HB VI (h.25-59). Sebenarnya keleluasaan Jawa mengenal Islam telah dimulai sejak Sunan Kalijaga, seorang bangsawan Majapahit yang semenjak kecil dibesarkan pada lingkungan priyayi dan kebudayaan Jawa. Singkat cerita, Kalijaga lantas berguru kepada Sunan Bonang dan menjadi senopati dari Sultan Agung pada imperium Mataram awal. Berangkat dari peranannya, hubungan Jawa Hindu dan Jawa Islam terjalin erat hingga pada karya sastra di kerajaan Mataram Islam era abad XVIII-XIX (Simuh, 1984, p. 89).

\section{Kesimpulan}

Warna Islam pada teks SDP tidak terpaut jauh dari teks induknya, Ambya. Corak aksara istana pada kedua teks tidak lantas membuatnya berjarak dengan kawasan pesantren di luar benteng keraton. Akan tetapi, para carik-carik istana justru seolah memboyong teksteks Islam ke dalam istana. Fakta ini diperoleh dengan menjamurnya teks bernuansa tasawuf yang berkembang di dalam istana. Berbagai penyesuaian etika bersastra di istana yang terus di patuhi pun memberi dampak baik pada penulisan Sastra Islam. Dengan demikian, perkembangan teks-teks bernuansa Islam tidak hanya terjadi di kawasan pesisiran dan atau pesantren.

Perbandingan yang sangat menyolok adalah ciri khas iluminas, kertas eropa, corak aksara yang halus dan rapi menjadi hal cermin dari tradisi tulis di istana-istana. Hal ini ditunjukkan oleh teks SDP. Secara kazanah sastra, kandungan teks SDP dapat dikatakan sebagai sastra Islam-Jawa yang menyerap banyak unsur ke-Islaman. Berbagai diksi Islam, gambar, dan lafal arab dibubuhkan sebagai bentuk dari legitimasi Islam di dalam roh Jawa. 


\section{Referensi}

Behrend. (1990). Katalog Induk Naskah-naskah Nusantara. Jakarta: Djambatan.

De Graaf, H. J. dan T. G. T. P. (1989). Kerajaan-kerajaan Islam di Jawa: Peralihan dari Majapahit ke Mataram. Jakarta: Grafiti Pers.

Drewes, G. W. J. (1974). Ranggawarsita, the Pustaka Raja Madya and the Wayang Madya. Orient Extremus. (pp. 199).

Kuntowijoyo. (1984). Agama dan Seni, Beberapa Masalah Pengkajian Interdisipliner Budaya Islam Di Jawa. Yogyakarta: Proyek Javanologi Museum Sonobudoyo.

Molen, W. van der. (2011). Kritik Teks Jawa (Sebuah Pemandangan Umum dan Pendekatan Baru yang Diterapkan kepada Kunjarakarna). Jakarta: Yayasan Obor Indonesia.

Muhaimin, A. G. (2006). The Islamic Tradition of Cirebon: Ibadat dan Adat among Javanese Muslims. Canbera: ANU E Press.

Poerwadarminta, W. J. . (1939). Baoesastra Djawa. Batavia: J.B. Wolters Uitgevers Maatschappij n. v.

Prabowo, D. (2003). Pengaruh Islam dalam Karya-karya R.Ng. Ranggawarsita. Yogyakarta: Narasi.

Pujiastuti, T. (n.d.). Poerbatjaraka dan Manuskrip Islam. Jakarta: Perpustakaan Nasional Republik Indonesia.

Riyadi, S. (2002). Tradisi Kehidupan Sastra di Kasultanan Yogyakarta. Yogyakarta: Gama Media.

Roorda, en G. (1901). Javaansch-Nederlandsch Handwoordenboek Deel I-II. Amsterdam: Leiden Boekhandel en Drukkerij voorheen E. J. Brill.

Saktimulya, S. R. (1998). Fungsi Wedana Renggan dalam Sestradisuhul. Yogyakarta: Pascasarjana Universitas Gadjah Mada.

Samidi. (2016). Tuhan, Manusia, Alam: Analisis Kitab Primbon Atassadhur Adammakna. Jurnal Shahih, 13-26.

Simuh. (1984). Unsur-unsur Islam dalam Kepustakaan Jawa. Yogyakarta: Proyek Javanologi Museum Sonobudoyo.

Simuh. (1998). Kitab Ambiya Jawi versi Kraton Yogyakarta (Islam dan Khazanah Budaya Kraton Yogyakarta). Yogyakarta: Yayasan Kebudayaan Islam Indonesia.

Wirjosaputro, S. R. . (1964). Glimpses of Cultural History of Indonesia. Jakarta: Indira.

\section{Naskah}

\section{Sĕrat Ambya}

Kode koleksi: L25j (SK 132). Museum Sonobudoyo.Yogyakarta.

\section{Sĕrat Dahor Palak}

Kode koleksi: S1 (SK 100). Museum Sonobudoyo.Yogyakarta.

\section{Sĕrat Jatipusaka (Dahor Palak) saha Sĕrat Momana}

\section{Sĕrat Tajusalatin}

Kode koleksi: S3 (PB E 100). Museum Sonobudoyo.Yogyakarta.

Kode koleksi: L335 (PB A 197). Museum Sonobudoyo.Yogyakarta. 


\section{Endnotes}

1. Sastra Islam Menak dikenal sejak Sultan Agung (1613-1645), dalam tulisan Poerbatjaraka, teks menak tertua ditemukan era Paku Buwana I (Kartasura) yang ditulis atas kehendak Kanjeng Ratu Mas Balitar (Permaisuri). Cerita ini yang terbagi ke dalam 24 jilid (berawal dari Menak Sarehas, hingga Menak Lakat), menurut Piegaud telah terkenal semenjak abad ke-16 (Simuh, 1984:1).

2. This period of renaissance lasted about 125 years. It can be said to gave begun after removal of the Kartasura kraton to Solo (Surakarta) in years 1745-46, perhaps more exactly, in 1757, after political situation in central Java had been consoliated by the partition of the realm of Mataram into three separate states under the suzerainty of VOC.

3. Sastra Islam-Jawa telah lama menjadi buruan para filolog dan peneliti manuskrip ( $M s)$. (Pujiastuti, n.d., 1950), mengistilahkan sebagai sastra pesantren, sedangkan Simuh (1988) menyebutnya tradisi Kepustakaan Islam Kejawen.Keduanya adalah hal yang serupa untuk mengategorikan Sastra Islam dan Mistik Jawa.Kondisi ini sebenarnya adalah produksi dari pola keseragaman yang dimunculkan melalui teori sinkretisme. Pandangan yang tidak menitik-beratkan pada benar atau salah, murni atau imitasi, baik atau buruk, melainkan pada keseragaman dan harmoni 'a movement to bring about a harmony of positions in philosophy or theology which are somewhat opposed or different, Runes, D.D (Simuh, 1984:2).

4. (Behrend, 1990) menyebutkan bahwa terdapat 30 sĕrat Ambya koleksi Museum Sonobudoyo, yang di dalamnya dimasukkan pula teks Dahor Palak sebagai salah satu variannya, tidak satupun dari ke-30 teks yang sama persis. Behrend mengelompokkan pula teks berdasarkan lokasi penyalinannya. Kecenderungan teks pesantren ditulis dengan aksara pegon, jumlah halaman yang sedikit, tanpa iluminasi, serta sampul naskah tidak terbuat dari kulit. Sedangkan teks penyalinan istana cenderung mewah. Sampul terbuat dari kulit, beriluminasi dengan tinta emas dan rubrikasi, jumlah halaman yang banyak (kode naskah Ambya, SK. 133 mencapai 1267 halaman), dan menggunakan aksara Jawa (corak kerajaan).Kertas yang digunakan pun adalah kertas Eropa yang bertanda air, sedangkan versi pesantren memilih menggunakan kertas bergaris yang diproduksi awal abad 19.

5. Teks SDP ditulis pada Selasa Kliwon, 13 Rabingulakir, Jimawal 1773, Tri Wiku Pandhiteng Rat (21 April 1845) (bdk.S 3/ PBE 100).Pada naskah ini terdapat 2 episode teks SDP, (h. 1-24) berkisah kronogram nabi-nabi semenjak Adam hingga Khalifatullah (Sahabat Rasul) dengan tarikh kelahiran dan gambaran singkat kehidupan umat nabi.Sedangkan pada episode kedua (h. 24-58) berkisah tentang raja Jawa, 9 wali dan pembangunan masjid di Demak, Sultan Hadiwijaja, Panembahan Senapati hingga HB VI. Tarikh penobatan dan gambaran singkat dibubuhkan dalam cerita dan sengkalan(Behrend, 1990:1).

6. Sĕrat Jatipusaka (Dahor Palak) saha Sĕrat Momana (bdk.SDP) diprakarsai oleh K.P.H. Suryanegara (putra HB IV), ditulis pada 1 Januari 1865, kemudian disalin atas prakarsa K.H.P. Hadiwijaya (putra HB VII) pada 2 November 1882. Atas prakarsa R.T. Cakraningrat (bupati nayaka jawi tĕngěnbumija), teks ini disalin kembali pada 8 Januari 1883 dan akhir penyalinan dilakukan oleh R. Atmamarta selama 1-27 Juli 1912 atas prakarsa R. L. Mangkudigdaya (lurah punakawan ordenas, menatu K. R. A. 
Danureja VII, P. A. Cakraningrat) koleksi Pigeaud di Biro Naskah, F.S. Universitas Indonesia (kode Nr-ThP 507), Moens, Ir., menyumbangkan transliterasinya 1941 di Panti Boedaja (Behrend, 1990:2).

7. Tajusalatin (PBA 197) disalin pada Kemis Legi, 6 Jimawal, Ehe 1780 (Sirnesthi Turanggeng Katong), 26 Februari 1852. Sedangkan pada teks Ambya disalin pada 9 Sawal, Jimawal 1878 (Bumi Esthi Pandhita Ji), 16 Juli 1853 (Behrend, 1990:412-3). Kedua teks tersebut berada pada periode penyalinan yang sejaman di awal abad XIX. Corak penulisan yang ngĕtumbar serta iluminasi yang dibubuhkan memiliki ciri yang serupa. Penggunaan ilustrasi seperti naga, pěksi, dan sulur-sulur dominan di kedua naskah. Dari hasil pengamatan inilah, teks Tajusalatin digunakan sebagai pembanding teks Ambya dan SDP.

8. Wĕdana adalah gambar ornamental yang membingkai teks, dengan pola wĕdana rĕnggan, gapura rĕnggan, dan rĕrĕnggan (Saktimulya, 1998:2). Sedangkan jika ditinjau dari makna ilustrasinya, wĕdana rĕnggan dapat berfungsi sebagai visualisasi dari kandungan teks yang sedang diceritakan.

9. Serupa dengan sĕrat Ambya (SK 132) berasal dari luar pesantren, melainkan saduran keraton pada masa HB V (1822-6, jeda dan dilanjutkan 1828-55). Teks disalin oleh R. Arya Suryamisesa pada 28 Februari 1844 -15 Juni 1851 (Behrend, 1990:220). Riclefs $(2008,193)$ (tidak ada di dapus) membenarkan bahwa masa Sultan Menol mendorong semangat penulisan karya sastra dan secara bertahap. Puncak masa penulisan dan penyalinan tersebut terjadi pada 1846-1855 yang mencatat 121 naskah baru (Riyadi, 2002:37). Perpustakaan keraton (yang sekarang bernama Widyabudaya) dibangun kembali secara bertahap hingga puncak pembangunannya terjadi pada masa HB VII.

10. Kepercayaan nenek moyang (animisme-dinamisme ataupun Hindu) nampaknya cukup memaksimalkan peranannya sebagai budaya yang diwariskan. Mulder (1983)(tidak ada di dapus) membenarkan bahwa tradisi bersastra yang dilakukan oleh pujangga termasyhur, Yasadipura I-II, Ranggawarsita, hingga kalangan istana PB IV dan MN IV bertindak menjembatani Islam (melalui tasawuf) untuk dapat tumbuh subur di kalangan sastra Jawa. Tasawuf selanjutnya dirasa cukup supel dan mampu berasimilasi dengan baik dengan menerima warna tradisi (Prabowo dkk, 2003:22).

11. Basara atau baswara berarti 1) menyala, 2) matahari (Roorda, 1901), Baswara juga dapat berarti 1) cahaya yang memancar, 2) menggelegar (Poerwadarminta, 1939) Pada konteks ini terjemahan abu basara mengacu pada asal muasal penciptaan Nabi Adam yang digambarkan dari tanah bercahaya.

12. Kesetiaan dari Nabi Sis yang dikutip dari teks SDP "mung nabi Sis kan tan pisah, lan rama nabi Adam, reh ginadhang-gadhang luhure, těmbe gumanti ing rama" (SDP Asmaradana, 12). Kelak Nabi Sis inilah yang menggantikan Nabi Adam untuk menjadi utusan Tuhan di dunia.

13. Kepergian Nabi Adam di usia 690 dijelaskan pula pada teks "nabi Adam yuswanira, pan sangang atus warsa, sawidak ing langkungipun, kang kocap ngumdatul asab (SDP Asmaradana, 16).

14. Kelahiran nabi Isa dari Dewi Maryam, agaknya menimbulkan pertanyaan sebab Isa tidaklah berayah.Ia lahir dari seorang ibu tanpa suami. Ketika itu pula nabi Sis mendakwa sang Ibu agar bertaubat kepada sang Pencipta. Padahal di sisi lain diutarakan bahwa melalui malaikat Jabarail (Jibril), Isa didaulat sebagai nabi kekasih sang Ywang Widi yang diberi kitab Injil sebagai perintah utama untuk membimbing Bani Israil. 
Pedoman hidup itulah yang menjadi panutan (SDP Kinanthi 5-9).

15. Cerita Muhammad sebagai bentuk perkembangan sastra Islam di istana berbicara persoalan syariat sebagai dasar fundamental. Simuh $(1984,3)$ mengungkapkan bahwa syariat berfungsi sebagai pembeda dari ajaran yang lurus dan menyimpang. Dikatakan pula oleh (Muhaimin, 2006:209) bahwa cerita Nabi Muhammad merupakan era Islam yang memiliki dasar kuat, bukan turunan melainkan bersumber dari ajaran Islam yang sungguh.

16. Habibullah ummiy (Arab), yang berarti adalah kekasih Allah yang cerdas. Selanjutnya kabibollah umiyil dimaknai dengan hal yang sama.

17. Umat Islam berada di pasca sepeninggalan Rasul diperintah oleh Abu Bakar (Sultan Sidik Abu Bakar) (SDP, Asmaradana, 1-3), pemerintahan dilanjutkan oleh Umar, sosok yang penuh wibawa.Dikatakan dalam kepemimpinannya, Umar bersifat sěmbada. Memerintah cukup lama, sebelum digantikan oleh Sayidin Usman (SDP, Asmaradana 4-7). Pada pemerintahannya, Usman dikenal sebagai pemimpin yang sangat bersih. Jabatan adalah amanah yang wajib dipertanggungjawabkan (SDP, Asmaradana 8-10). Hingga sampai pada kepemimpinan terakhir yaitu Sayidin Ali, sosok yang dikenal sangat kasar sekaligus halus. Pemimpin yang peuh ikhlas dan digdaya dalam peperangan (SDP, Asmaradana 11-15). 
